\title{
The Implementation of Training Management Applied By the Pnpm Mandiri Perkotaan Facilitator to Self-Help Groups
}

\author{
Achmad Rasyad \\ (Faculty of Education, State University of Malang East Java, Indonesia)
}

\begin{abstract}
This study was aiming at explaining (1) the role of the facilitator in the implementation of the empowering training by PNPM MandiriPerkotaan, (2) the planning process applied by the PNPM MandiriPerkotaanfacilitator to the self-help groups, and (3) the training process held by the facilitator of PNPM MandiriPerkotaanto the self-help groups. This study took place in KecamatanKepanjen, Malang regency. The primary informant was the facilitator of kelurahan, while the supporting informant came from the committee ofBadanKeswadayaanMasyarakat (the self-help group institution), members ofthe self-help groups, and the local government. The finding of the study was the facilitator of PNPM MandiriPerkotaanplayed double roles. It meant that the facilitator did not only facilitate the needs of the study, but also they had to play the role of learning sources, teachers, and mediators. (2) The well-planned training would bring significant effect. (3) Training was not only aimed to deliver the training materials, but also the facilitator had to apply communicative technique to the trainees.
\end{abstract}

Keywords: Training Management, Facilitator, Self-help Groups.

\section{Introduction}

There are several kinds of Independent PNPM; one of them is PNPM MandiriPerkotaan. PNPM MandiriPerkotaanis a national program focusing on reducing the poverty by enhancing the poor's access to housing and settlement in the urban area by using participative principle. PNPM MandiriPerkotaanaims at helping the poor in the urban area to live in a better environment and better governmental system. (Desyani, 2013: 24),

To achieve the goal, one of the strategic approaches used is by developing the quality so that all the participants in the level of society, consultant, and local government are able to implement the program well. Moreover, the participant of the empowering program could be independent learners. One of the quality development programs in the PNPM MandiriPerkotaan is done through trainings.

The government policy which orients to the society, which is PNPM Mandiri, is expected to create independency and prosperity to solve the poverty problem (Nurhayatun, 2013: 1119). Unfortunately, the participative performance is still in the level of society representation and it has not been optimal yet.

Even though PNPM has been issued in all over the country, the World Bank (2013: 30) points that the rate of poverty reduction in Indonesia is getting slower in several years lately. Furthermore, in line with the slow economic growth, inflation risk, and high price of rice, the prospect of the poverty rate in the second half of 2013 and the first half of 2014 should be watched carefully.

Another problem which has to be the watched by the Indonesian government is the unemployment. This is not an easy matter to decrease the unemployment level because there are many challenges faced by the government in order to enhance the quality of human resources. Even, many are pessimistic of being able to fix this matter. One of the indicators is the level of unemployment is still relatively high. Before 2009, the government had targeted to decrease the level of unemployment to $5.10 \%$. Even though this is not ambitious, in 2010, the level of unemployment has decreased 384.000 (Hanurahmawan, 2010: 78).

PNPM MandiriPerkotaanattempts to implement training to the self-help groups to solve the poverty and unemployment. From a bunch numbers of trainings, many of them have not been giving significant effects. Thus, to solve the problem of the training, it is important to have training management and optimum participation from the society and the supporting components.

\section{Methods}

This study used qualitative approach with a research design namely one case study happened in the PNPM Perkotaanof KecamatanKepanjen, Malang regency. This study applied the constructivist paradigm which believed that the social science was as the systematic analysis of socially meaningful action. It involved the direct observation to the social behavior in the setting of natural daily life, so the social behavior of the particular party could be understood, especially concerning to how their behavior could create and maintain their social life (Hidayat, 2003). 
The data sources were purposively chosen through the facilitator fromKelurahan(as the primary informant). The supporting informants were the member of KSM (KelompokSwadayaMasyarakat), the committee of BKM (BadanKeswadayaanMasyarakat), and the society. In order to obtain the data, the researcher did comprehensive interview, focus group discussion, observation, and documentation. To answer the research question, the researcher used analysis technique proposed by Miles \&Huberman which involved 4 steps: (1) data collection, (2) data reduction, (3) data display, and (4) conclusion: drawing/verification (Miles \&Huberman, 1994: 12)

\section{Results}

\section{The Role of Facilitator in the Empowering Training through PNPM MandiriPerkotaan}

In the empowering training, the facilitator played roles of giving technical guidance and empowering them to reach the goals. These roles were very crucial, therefore in the process of training, a facilitator had to respect the value of democracy, responsibility, cooperation, honesty, and equality.

The result of an interview with facilitators showed that a facilitator of PNPM MandiriPerkotaanplayed two roles in a time. They did not only facilitate the learning needs of the society, but also became the teacher who guided and taught them of how to solve the problem of poverty through group activities. Another role played by the facilitator was becoming a role model for the trainees. For example, a facilitator could not expect the trainee to be punctual if he or she was not punctual as well. Even though the facilitator had been on time, many of the trainees barely made it punctual. Furthermore, a facilitator should have been able to guide. The society definitely needed guidance. If not, they would find many difficulties because most of the human resources were still low.

Facilitators from kelurahan played the duty of covering the kelurahan or villages within a kecamatan. It was expected that the empowering process could be done simultaneously. Most of the facilitator held bachelor's degree from any majors. Although they were well-educated, their experience should also have been a consideration. From the help from the facilitators, it was expected that the society could employ their surrounding's potential as well as independent development.

In order to perform their duty well, a facilitator had to comprehend their role as a facilitator in the society. Based on the field observation, the role of facilitators was very significant in the training; not only as the informant, but also as teachers and mediators. Moreover, facilitators had to have particular competences: communicative skill, role model skill, confidence, icebreaker, leadership skill, developing skill, conceptual skill, and human learning.

When a facilitator had been recruited, they should have learned about both theoretical and practical materials so that they could get closer to the society. However, this still had not been able to answer the question in facilitatingthe society to study. Trainings basically were not only given before performing the duty, but also they were given when the facilitators had worked. This was to improve their performance. Rasyad (2014: 106) explained that the training is not only given to those who have not been on duty yet, but also to those who have worked for some periods of time in order to improve their performance.

The initial process of facilitating done by the facilitator getting to know the situation, the potential and social life, economy, and cultures in order to understand the people's need in the empowering program. The identification was done by visiting villages to observe and interview the society to get the idea of their condition, potential, and habits. In this step, the facilitator would introduce themselves to the society, approach the community leader, and explain their existence as a facilitator who would help the society through the PNPM MandiriPerkotaanProgram.

The participative communication in the empowering program could be observed in every single communicative activity. In this process, the role of a facilitator would determine whether the communication went participative or not. This was because the facilitator became the spearhead of empowering program. Therefore, the facilitator's role in the implementation of empowering training through PNPM was very crucial.

\section{The Planning Process of Training Applied by the PNPM MandiriPerkotaanFacilitators to The Self-Help Group}

The planning process of training done by PNPM MandiriPerkotaanwas: (1) the facilitators, BKM, and volunteers identified the learning needs and defined the priority as well as arranged the plan; (2) the committee of the training could possibly use the existed KSM. If there was no KSM, BKM and the volunteer could facilitate the forming of committee, (3) the committee made the training proposal. This proposal was allowed to be consisted of several kinds of training, which depended on the needs. The proposal was proposed and then a scoring would be carried out, (4) the committee then verified the materials. If there was revision, the materials would be rearranged. If there is no revision, the materials would be get recommendation to get an agreement. A recommendation would be given to appropriate trainings. If the fund sources came from the BLM, the recommendation would be given by the facilitator team. But if it came from the local government or other institutions, the recommendation would come from those who donated the fund, (5) BKM and facilitators from kelurahan identified candidate ofthe guide 
and informant of the training. They consolidated the materials and preparations, (6) if the fund sources were BLM, then the fund would be given based on the certain policy. There would be fund collecting by the self-help group and channeling from other parties, (7) the training was carried out based on the recommended proposal, (8) the committee and facilitator teams made a report of the implementation of the training and fund using, and (9) they presented the report.

The training could possibly be carried out everywhere as the society's agreement, as long as the place was conducive and comfortable for the training. Based on the field finding, the training was usually done in a hall of kelurahan or village. If the hall was used for another agenda, the training was done in a school building. The room setting and the seating arrangement played significant role in making the training situation became more participative. These two factors would affect to the learning process during the training. From the result of observations, the researcher found out that the seating in the training was arranged based on the class system.

A training informant was the one who facilitated the training process. A good informant had to be able to deliver knowledge, understanding, and experiences needed in the training. The informant could come from many parties, such as volunteers, BKM, facilitators, local government, or other institutions. Due to the fact that the training in PNPM Mandiri was done step by steps, the informants mostly came from internal party, which was facilitator from kelurahan.

The training committee was established in a participative way by BKM and the society. The organization structure depended on the needs and the agreement made by the society. The committee was allowed to use the existed KSM. The committee was divided into two, namely guide committee and executive committee.

The fund source could possibly came from some ways, such as: (1) independent fund, (2) channeling with other party, (3) fixed cost from the society, (4) direct fund from the society, and (5) other sources. The mechanism of the training paid by the fixed cost or BLM was determined by the PNPM Mandiri.

A well-planned training was expected to give a significant effect to the training result. By having a good plan which involved all the components, it was expected that the training would lead to a high quality training program. Rasyad (2014: 35) stated that participants, trainers, training materials, and working environment become significant factors. This was because those components fully supported the success of training. There were several crucial components in the training, namely: (1) the trainees; they played an important role because their active participation, number, and attitude would make the training went well. So, the trainee affected the training result directly. (2) The training environment; the environment also played the significant role in the training process. A training environment which was not conducive (such as the room with hot atmosphere, improper lighting, noisy surrounding, and too small room) would make the training went less smoothly.

Moreover, trainers and training materials were also importantly needed in the training process. However, Rasyad (2013: 35) pointed out that "the instructors and training materials contribute the training result indirectly". In other word, the facilitators and materials were important, but they did not give direct impact to the training result.

\section{Discussion}

\section{The Training Process Applied by the PNP MandiriPerkotaan Facilitators to The Self- Help Group}

The implementation of training done by the facilitator of PNPM MandiriPerkotaanin KecamatanKepanjen was not only delivering the training material; which was responded by the trainee with coming, sitting, keeping silent, and listening. The training was carried out in such participative was by applying a communicative facilitating technique to the trainees. Even, there was a session in which a trainer from the outside institution came to motivate the trainees. This activity was done because it was believed that a motivational training would be more effective and right on the target. The motivational training could lead the trainees to have a paradigm and positive mental attitude which supported the attempt to reduce the poverty.

The process of the training in the village or kecamatan had been run based on the curriculum. However, there was no guarantee that the training result would meet the expectation precisely. It depended on the society in understanding and implementing the program that had been agreed. Although the PNPM had been held in all over the country and it had touched the level of society, some parts of the implementation were still notaccording to the general operational guidelines

The obstacle found by the facilitator in the training process was: (1) the number of facilitators was still low; only 5 facilitators in a kecamatan, while the number of villages which got help from PNPMwas high, (2) the limited number of facilitators made the training was divided per area within a time, (3) a training for KSM which was supposed to be done 2 days in a row was done in 2 days, but not in a row.

In the field, it was found that there was a gap between the felt-needs and the objective-needs. This gap would not be a matter if the trainees had enough experience. "In fact, there was a gap between the felt-needs and objective-needs in the education practice. This gap should have not existed if the society had enough experience.'(Rasyad, 2014: 113). 
Another consideration that had to be paid attention to was the existence of trainers. If every kelurahan or village had trainers, the step-by-step training would be the best option. However, if the number of trainers were limited, then the best choice would be trainings within days. This also had to consider how far the trainees' house from the training place.

By having explanations and participative dialogues through trainings to the society, it was expected that they could get more knowledge and skills. They were also expected to be more aware of their surroundings. By doing so, the society was able to make decision of problems they were facing. The aspects that had to be improved through trainings were the equality of chances to speak up the idea, the communication between the society, confidence, access to information, the skill to manage the organization, the particular skills, the togetherness in decreasing the level of poverty, and the skill to motivate people to improve their prosperity (Mubarak, 2010).

\section{The Evaluation Process Applied by PNPM MandiriPerkotaanFacilitators to TheSelf-Help Group}

Evaluation was a new term which had developed to be a new branch of science. Stufflebeam\&Shinkfield (1985: 159) stated:

evaluation is the process of delineating, obtaining, and providing descriptive and judgmental information about the worth and merit of some object's goals, design, implementation, and impact in order to guide decision making, serve needs for accountability, and promote understanding of the involved phenomena.

On the other hand, Stark and Thomas (1994: 12) pointed out that "evaluation is the process of as certaining the decision of concern, selecting appropriate information, and collecting and analyzing information in order to report summary data useful to decision maker in selecting among alternatives." Those concepts of evaluations were used as the base of decision making. In the national project of empowering the society, the result of evaluation was used as the indicator whether a project was successful in achieving the goals or not. It was also used to know the obstacles occurred in the field.

Table1: Learning Topic Evaluation

\begin{tabular}{|c|c|c|c|c|c|}
\hline \multirow{2}{*}{ No } & \multirow{2}{*}{ Aspect } & \multicolumn{4}{|c|}{ Score } \\
\hline & & Very Good & Good & Enough & Need Improvement \\
\hline 1 & The benefit of materials & & & & \\
\hline 2 & The goals achievement & & & & \\
\hline 3 & The class dynamics & & & & \\
\hline 4 & The facilitator skill & & & & \\
\hline 5 & The committee support & & & & \\
\hline
\end{tabular}

In the training process, many of the PNPM MandiriPerkotaancommittees did the evaluation only in the end of the activity. The evaluation should have been done from the beginning of the program, starting from the program planning, program implementation, and the result of the training (Widyoko, 2012: 1). Moreover, Tjoetra, et all (2008) said that ideally the evaluation had to be able to score and it had to be done objectively and systematically. It was expected that the committee could contemplate the relevancy and the goals of the program, the efficiency of the program development, the effects, and the sustainability of the potential. The evaluation result should have given credible and usable information as well as spaces to integrate the value in the decision making between the donor and the partner given the donation (OECD/DAC, 1992).

The evaluation result would be presented based on the needs of the stakeholders. This was important to do due to the fact that not all stakeholders needed the similar information. For example, the field work level would need different information from the program management level. The program management level would also need different information from another level (Tjoetra, et all, 2008).

\section{Conclusions}

The success of an empowering training in PNPM MandiriPerkotaanis definitely affected by the planning step and the roles of the training facilitator. (1) The facilitators in PNPM MandiriPerkotaanplay double roles. A facilitator does not only facilitate the need of learnings of the society, but they also have to be able to play the role of teacher and mediator regarding to the various needs of the society. (2) A good plan will give big impact in the training process. If in the planning process there are some steps skipped, there is a big chance that the training will fail. (3) The training is not only involved the facilitators to deliver the material, but it also involves the communicatively facilitating technique to the trainees.

\section{Recommendation}

(1) It is essential to select the facilitators carefully to get high quality facilitators. The facilitators should be the expert in the empowering program and they graduate from the relevant majors. (2) The planning should involve the choosing of training location, the distance of the location, the use of media and learning materials. (3) 
It is suggested to the society to realize that the training is not only their duty and it is for the sake of the projects. The facilitator has to create participative dialog to raise the society's awareness so that they are able to be independent.

\section{Acknowledgement}

The researcher would like to thank (1) LembagaPenelitiandanPengabdiankepadaMasyarakat (LPPM)of State University of Malang who facilitate the independent research, (2) The Dean of Faculty of Education of State University of Malang, (3) The reviewers: Prof. Dr. Ach. Fatchan, M.Pd, M.P. and Prof. Dr. Supriyono, M.Pd. and (4) All people who helped the researcher in the process of research.

\section{References}

[1]. Desyani. 2013. The Analysis of Program Nasional Pemberdayaan Masyarakat Mandiri (PNPM Mandiri) in Kelurahan Sidodadi Samarinda Ulu. eJournal Sosiatri-Sosiologi, (Online), 1 (2): 23-35, (Error! Hyperlink reference not valid.), accessed on 2 January 2014.

[2]. Hanurahmawan, F. 2010. The Revitalization of Worker Training Management: Case Study at Balai Latihan Kerja Industri Makassar.Administrasi Publik, (Online), 1 (1) 78-94. (http://ojs.unm.ac.id/index.php/iap/article/ download/135/26), accessed on 2 January 2014

[3]. Hidayat, D.N. 2003. Paradigm and Research Methodology of Classical Social Empiric. Jakarta: Departemen Ilmu Komunikasi FISIP UI.

[4]. Miles, M.B. \& Huberman, A.M. 1994. Qualitative Data Analysis: A Sourcebook of New Methods. Beverly Hills, CA: Sage.

[5]. Mubarak, Z. 2010. The Evaluation of Society Empowering in Terms of Capacity Development Process in PNPM Mandiri Perkotaan in Sastrodirjan Village, Pekalongan Regency. Unpublished Thesis. Semarang: PPs Undip

[6]. Nurhayatun. 2013. The Review of Program Nasional Pemberdayaan Masyarakat (PNPM) Mandiri Perkotaan from Economic Aspect in Kelurahan Karang Mumus Kecamatan Samarinda Kota Samarinda. eJournal Ilmu Administrasi, (Online), 1 (3), 8118-8132 (www.ejournal.an.fisip-unmul.org), accessed on 1 January 2014.

[7]. Organization for Economic Cooperation and Development (OECD). 1992. Development Assistance Manual: DAC Principles for Effective Aid. Paris: Organization for Economic Cooperation and Development.

[8]. Rasyad, A. 2014. Reassessing PLKB Basic Training Curriculum In East Java. Interdiscipnilary Juornal of Contemporary Research in Business, (Online), 5 (11): 105-117, (http://www.ijcrb.webs.com), accessed on 20 April 2014.

[9]. Rasyad, A. 2013. The Effective Training Management Model of Learning Guardian in BPPLSP Surabaya, Indonesia. Journal of Education, 6 ((1): 35-41.

[10]. Stark, J.S. \& Thomas, A. 1994. Assesment and Program Evaluation. Needham heights: Simon \& Schuster Custom Publishing.

[11]. Stufflebeam, D.L. \& Shinkfield, A.J. 1985. Systematic Evaluation. Boston: Kluwer Nijhof Publishing.

[12]. Tjoetra, A., Jodas, N.E., Fuady, M., Iskandar, A.T., Hendrik, D. \& Syahrizal, T.B. 2008. Training Guideline: Planning, Monitoring, and Evaluating Program(F. Abdullah \& H. Soetomo Ed.). Penerbit Impact: Banda Aceh.

[13]. Widoyoko, S.E.P. 2012. $\quad$ Evaluating $\quad$ Training (http://file.upi.edu/Direktori/SPS/PRODI.PENDIDIKAN_IPA/197102041997021NAHADI/Evaluasi\%2520Program\%2520Pelatiha n.pdf), accessed on 16 March 2014. 